\title{
GREEN HISTORY DALAM BUKU TEKS SEJARAH
}

\author{
Hena Gian Hermana \\ Guru Sejarah di SMK Negeri 11 Bandung \\ hermanahenagian@gmail.com
}

Abstract: $\quad$ History textbooks for high school are one form of material used for the purpose of learning in schools. History learning serves to preserve the collective memory and values that are considered important, one of which is caring about the environment which is an important value in the ecocentric perspective part of green history. This study aims to reveal depictions and representation of the value of green history in history textbooks. The method used is content analysis. The data source in this study is the X grade High School History textbook based on the 2006 curriculum by I Wayan Badrika published by Erlangga. The results showed that green history was represented in various themes such as the early life of Indonesian people (hunting and gathering food and farming and farming), and ancient Asian-African civilizations (Shindu and Ganges, Yellow River, and Eufrat and Tigris Rivers) ) Green History needs to be understood as a way to develop students' minds about the importance of protecting environmental awareness (understanding how nature sustains life) such as decision making (decision making skills) in carrying out various actions in daily life.

Abstrak: $\quad$ Buku teks Sejarah untuk SMA merupakan salah satu bentuk material yang digunakan untuk kepentingan pembelajaran di sekolah. Pembeljaran sejarah berfungsi untuk melestarikan memori kolektif dan nilai-nilai yang dianggap penting, salah satunya peduli lingkungan yang merupakan nilai penting dalam cara pandang ecocentris bagian dari green history. Penelitian ini bertujuan untuk mengungkap penggambaran dan representasi nilai green history dalam buku teks sejarah. Metode yang digunakan yaitu content analysis. Sumber data pada penelitian ini adalah buku teks Sejarah SMA kelas X berdasarkan kurikulum 2006 karya I Wayan Badrika yang diterbitkan oleh Erlangga. Hasil penelitian menunjukkan bahwa green history direpresentasikan dalam berbagai tema seperti kehidupan awal masyarakat Indonesia (masa berburu dan mengumpulkan makanan serta masa beternak dan bercocok tanam), dan peradaban kuno Asia-Afrika (Peradaban Sungai Shindu dan Gangga, Sungai Kuning, dan Sungai Eufrat dan Tigris). Green History perlu dipahami sebagai cara untuk mengembangkan pikiran peserta didik tentang pentingnya menjaga kelestarian lingkungan (understanding how nature sustains life) seperti pengambilan keputusan (decision making skills) di dalam melakukan berbagai tindakan di dalam kehidupan sehari-hari.

Kata Kunci: $\quad$ Peduli lingkungan, green history, buku teks sejarah

\section{PENDAHULUAN}

Dalam masa pembangunan bangsa, salah satu fungsi utama pendidikan tidak lain ialah upaya pengembangan kesadaran nasional sebagai sumber daya mental dalam proses pembangunan kepribadian nasional beserta identitasnya. Struktur kepribadian nasional tersusun dari karakteristik perwatakan yang tumbuh serta melembaga dalam proses pengalaman sepanjang kehidupan bangsa. Dengan demikian, kepribadian nasional serta identitas bertumpu pada pengalaman kolektif bangsa. Jadi, pada sejarahnya. Dalam konteks pembentukan identitas nasional, pengetahuan sejarah mempunyai fungsi fundamental (Kartodirdjo dalam Aisyah, 2015).

Lembaga pendidikan formal (sekolah) berperan untuk mencerdaskan kehidupan bangsa. Sekolah sebagai suatu lembaga formal secara sistematis merencanakan bermacammacam lingkungan, yakni lingkungan pendidikan yang menyediakan berbagai kesempatan bagi peserta didik untuk melakukan berbagai kegiatan belajar (Hamalik, 2008, hlm. 3). Dengan demikian, sekolah sebagai penyelenggara pendidikan formal memiliki tugas menciptakan output yang berkualitas dari hasil proses belajar.
Sadiman, et.al. (2007, hlm. 2) mengungkapkan bahwa belajar adalah suatu proses yang kompleks yang terjadi pada semua orang yang berlangsung seumur hidup dari semenjak ia lahir sampai ia meninggal yang ditandai dengan adanya perubahan tingkah laku yang bersifat pengetahuan (kognitif), keterampilan (psikomotorik), maupun menyangkut nilai dan sikap (afektif). Dalam belajar, seseorang mengalami perubahan tingkah laku, namun tidak semua perubahan tingkah laku bisa disebut belajar, misalnya orang yang berubah tingkah lakunya setelah minum alkohol. Contoh tersebut tidak termasuk ke dalam belajar, karena tidak ada interaksi dalam lingkungan. Jadi, pada hakikatnya belajar haruslah ada perubahan tingkah laku sebagai akibat dari interaksi dengan lingkungan.

Dewasa ini, kedudukan buku teks menjadi semakin sentral dalam proses belajar mengajar karena guru merasa sulit dan berat untuk mengembangkan sendiri materi pelajaran yang diampu, entah karena alasan waktu yang terbatas ataupun tekanan eksternal. Mengingat kedudukan buku teks penting dalam proses belajar mengajar, pada tahun 2005 Departemen Pendidikan Nasional mengeluarkan Peraturan Menteri Pendidikan Nasional (Permendiknas) No. 11 Tahun 2005 tentang Buku Teks Pelajaran. Pada pasal 3 ayat 1 diatur bahwa buku teks pelajaran untuk setiap mata pelajaran yang 
digunakan pada satuan pendidikan dasar dan menengah dipilih dari buku-buku teks pelajaran yang telah ditetapkan oleh menteri berdasarkan rekomendasi penilaian kelayakan dari Badan Standar Nasional Pendidikan (BSNP).

BSNP menetapkan empat kriteria utama buku teks, yaitu materi, penyajian, bahasa dan keterbacaan, serta grafika (Purwanta, 2012). Ketentuan BSNP tersebut berlaku untuk buku teks semua mata pelajaran, sehingga kriterinya bersifat elementer. Khusus untuk buku teks pelajaran sejarah, kriteria yang ditentukan oleh BSNP kurang memadai karena tidak mempu mencermati isi di dalamnya. Menurut Abdullah dan Surjomihar (1985) dalam (Purwanta, 2012) menjelaskan bahwa salah satu alat untuk mengkaji isi buku teks sejarah yakni dengan mengkategorisasikan model penulisan sejarah menjadi tiga jenis, yaitu sejarah ideologis, pewarisan, dan akademik. Artinya, buku teks sejarah di satu sisi harus mampu menjadi media pewaris, tetapi di sisi lain harus dapat dipertanggungjawabkan secara akademik.

Sartono Kartodirdjo (dalam Mulyana dan Darmiasti, 2009, hlm. 5) memberikan syarat-syarat untuk penulisan sejarah nasional, yaitu sebagai berikut:

1. mengungkapkan 'sejarah dari dalam' dimana bangsa Indonesia sendiri memegang peranan pokok;

2. menguraikan faktor atau kekuatan yang mempengaruhinya, baik ekonomi, sosial maupun politik, ataupun kultural;

3. mengungkapkan aktivitas berbagai golongan masyarakat, tidak hanya bangsawan atau ksatria, tetapi juga dari kaum ulama atau petani serta golongan-golongan lainnya;

4. menyusun sejarah Indonesia sebagai suatu sintesa, dimana digambarkan proses yang menunjukkan perkembangan ke arah kesatuan geopolitik seperti yang kita hadapi dewasa ini, maka prinsip integrasi perlu dipergunakan untuk mengukur seberapa jauh integrasi itu dalam masa-masa tertentu telah tercapai.

Berdasarkan syarat-syarat di atas, kriteria Kartodirdjo nomor 1) dan 2) terkait dengan pendekatan yang dipilih oleh sejarawan Indonesia untuk merekonstruksi sejarah masyarakatnya. Di pihak lain, dari syarat/kriteria nomor 3) yang dibuat Kartodirdjo, yaitu aktivitas berbagai golongan masyarakat, dapat diambil pemahaman bahwa penulisan buku teks pelajaran sejarah harus memperhatikan 'keberimbangan'. Sebagai bangsa yang bhineka, buku teks sejarah Indonesia perlu mewadahi fenomena historis dari perspektif golongan, baik berupa kelas sosial, suku, agama, ras, maupun wilayah sehingga komposisinya dalam buku teks pelajaran sejarah relatif berimbang. Pandangan Kartodirdjo tersebut sesuai dengan pendapat Asvi Warman Adam yang menyatakan bahwa sejarah Indonesia sudah seharusnya menggambarkan berbagai etnik dan kekuatan yang ada di Indonesia (Purwanto dan Adam, 2005).

Pada syarat nomor 4), Kartodirdjo menyebutkan bahwa sejarah Indonesia disusun sebagai suatu sintesis, yaitu integrasi geopolitik nasional Indonesia. Dari sudut pandang ini, pemilihan peristiwa dan perspektif yang terpintal dalam uraian sejarah nasional sudah seharusnya bersifat teleologis atau menuju satu titik, yaitu integrasi nasional. Dalam konteks ini, teleologis dimaksudkan sebagai usaha menempatkan realitas historis kontemporer menjadi tujuan dari gerak sejarah masa sebelumnya. Dengan kata lain, berdirinya Negara Kesatuan Republik Indonesia pada tahun 1945 dipahami sebagai tujuan dari dinamika historis masyarakat periode-periode sebelumnya. Di pihak lain, penguatan dan pengembangan Negara Kesatuan Republik Indonesia dipahami sebagai tujuan dari dinamika historis periode-periode setelah tahun 1945 (Purwanta, 2012).

Pelajaran sejarah sekarang didominasi oleh kenyataan bahwa peserta didik diharuskan menghapal fakta sejarah, nama-nama konsep seperti yang digunakan dalam sebuah cerita sejarah, menghapalkan jalan cerita suatu peristiwa, fakto penyebab, akibat suatu peristiwa, dan sebagainya (Hasan, 2012, hlm. 129). Senada dengan Supriatna (2011) bahwa pelajaran sejarah lebih banyak didominasi oleh kegiatan menghapal dan mengingat nama tokoh, nama peristiwa, dan tahun kejadian (rote learning) mengenai kesinambungan dan perubahan (continuity and change) dalam narasi besar (grand narrative) sejarah nasional yang menekankan pada kejayaan masa lalu bangsa. Sehingga, kondisi inilah yang mengakibatkan pelajaran sejarah tidak memiliki makna atau kontribusi apapun di dalam kehidupan, atau dengan kata lain belajar sejarah itu hanya akan menjadi beban hapalan saja.

Kondisi seperti di atas, dipandang oleh Seixas (dalam Supriatna, 2011) hanya "berorientasi pada enhancing collective memory, sebab guru lebih banyak menyajikan the best story sebagai hasil dari interpretasi terpilih dari sejumlah interpretasi sejarawan mengenai masa lalu yang direkomendasikan oleh mereka yang berada dalam posisi memegang otoritas". Sehingga, diperlukan suatu paradigma baru berkenaan dengan rekonstruksi pelajaran sejarah yang berorientasi pada permasalahan-permasalahan sosial yang muncul pada saat ini.

Jika ditinjau dari segi prinsip-prinsip pengembangan kurikulum, K-13 mendasarkan prinsip pengembangan kepada prinsip relevansi pendidikan dengan kebutuhan dan lingkungan hidup. Artinya, kurikulum memberikan kesempatan kepada peserta didik untuk mempelajari permasalahan di lingkungan masyarakatnya sebagai konten kurikulum dan kesempatan untuk mengaplikasikan yang dipelajari di kelas dalam kehidupan di masyarakat. Dalam hal ini, ecopedagogy dapat dijadikan sebagai solusi alternatif dalam mengangkat isu lingkungan hidup serta konsep kesinambungan (sustainability) sebagai materi pembelajaran dan mengangkat hubungan manusia dengan lingkungannya. Dari pemikiran di atas, isu-isu yang menjadi concern dalam sejarah lingkungan menjadi kajian yang diintegrasikan dalam pembelajaran sejarah.

Sejarah lingkungan memiliki peran penting dalam kehidupan berkelanjutan dan pelestarian lingkungan. Upaya ini dilakukan dengan menerapkan pembelajaran sejarah berwawasan lingkungan (PSBL). PSBL merupakan upaya terintegrasi untuk mengenalkan sejarah lingkungan (environmental history) secara luas dan arti pentingnya bagi kehidupan manusia. Dengan demikian, penanaman kesadaran lingkungan menjadi tanggung jawab pendidikan sejarah (Ahmad, 2013, hlm. 75).

HISTORIA: Jurnal Pendidik dan Peneliti Sejarah, p-issn:2620-4789 | e-issn:2615-7993 
Konsep Green History dirasa dapat menjadi cara untuk merubah paradigma masyarakat terhadap pembelajaran sejarah yang memandang manusia sebagai pengendali alam (anthropocentrism) menjadi manusia sebagai bagian dari alam (ecocentrism). Dengan demikian, pelajaran sejarah sangatlah relevan menjadi suatu disiplin ilmu yang dapat mengembangkan pendekatan Green History sebagai pemahaman continuity of time and people juga hubungannya dengan tempat dimana manusia itu tinggal (Supriatna, 2014). Berdasarkan pemaparan di atas, penulis di dalam penelitian ini ingin melihat bagaimana green history memberikan warna baru pada penulisan buku teks. Green history yang dimaksud adalah keberadaan manusia sebagai bagian dari alam terutama dalam memenuhi kebutuhan hidupnya yang selaras dengan pelestarian alam. Dalam penelitian ini, penulis mencoba menggunakan konsep green history sebagai bentuk penanaman nilai dalam narasi buku teks pelajaran sejarah di SMA. Penulis akan mencoba mengkaji pada bagian-bagian mana pada buku teks pelajaran Sejarah SMA kelas X yang mengandung konsep tersebut.

\section{KAJIAN PUSTAKA}

\section{Buku Teks Sejarah}

Secara umum buku teks banyak diartikan sebagai buku pegangan bahan ajar siswa/mahasiswa di sekolah. Menurut Sjamsuddin (dalam Mulyana dan Restu, 2007, hlm. 195) buku teks ialah buku "pegangan guru" yang khusus ditulis sebagai pedoman guru yang kedalaman dan keluasan substansinya lebih daripada buku teks yang diperuntukkan bagi siswasiswinya; di dalamnya memuat tugas-tugas terstruktur dan non-struktur, latihan-latihan yang akan diberikan kepada siswa-siswa, sampai kepada sistim evaluasi yang akan digunakan guru. Jadi, buku teks merupakan salah satu bentuk material di dalam sistem pembelajaran.

Dalam kaitannya dengan pelajaran sejarah, maka buku teks adalah untuk kepentingan pendidikan sejarah. Dengan demikian, menurut Mulyana (2013) menjelaskan bahwa historiografi dalam buku teks pelajaran sejarah adalah rekonstruksi narasi sejarah yang dijadikan alat dalam pendidikan. ketika sejarah ditempatkan dalam ranah pendidikan maka akan terjadi interpretasi subjektif sejarah bagi kepentingan pendidikan. Pendapat lain, dari (Utami dan Widiadi, 2016, hlm. 110) menjelaskan bahwa historiografi buku teks bukanlah cerminan dari peristiwa masa lalu, namun ia hanya representasi dari realitas yang ditampilkan oleh penulisnya dalam bentuk narasi. Buku teks sejarah mengandung nilai-nilai atau ideologi tertentu. Hal ini karena salah satu tujuan pembelajaran sejarah adalah untuk melestarikan nilai-nilai yang dianggap penting.

Hal senada diungkapkan oleh Agus Mulyana (2011) yang dikutip oleh (Utami dan Widiadi, 2016, hlm. 108) bahwa kepentingan penanaman nilai atau ideologi dan kepentingan kajian kritis dalam buku teks seharusnya dapat dipadukan. Ideologi atau nilai-nilai dapat tertanam dalam diri siswa ketika membaca buku teks pelajaran sejarah secara kritis, bukan penanaman ideologi atau nilai-nilai yang bersifat indoktrinisasi. Dengan demikian, buku teks dipandang sebagai wacana yang merepresentasikan nilai-nilai dan ideologi.

\section{Green History}

Konsep green atau hijau adalah konsep yang sama digunakan dalam displin lain seperti green economy, green architecture, green energy, green design, dan lain-lain. Green History merupakan sebuah gugatan terhadap paradigma sejarah yang menempatkan manusia sebagai penentu dalam perjalanan sejarah (Supriatna, 2016, hlm. 105-106). Green History mencoba merefleksi kembali peristiwa-peristiwa di masa lau untuk orientasi keberlangsungan hidup di masa yang akan datang. Green History diidentikan pula dengan ecological history yaitu "increasingly sought as a guide for ecological interpretation” (Foster, 2010). Dengan demikian, green history berisi kajian yang bersifat tematis pada sejarah fisik alam, tumbuh-tumbuhan, semua makhluk hidup (hewan dan tumbuhan) dalam ekosistem dan bisa juga berisi kajian mengenai manusia sebagai pelaku sejarah dan dampaknya bagi lingkungan sosial, lingkungan hewan, lingkungan tumbuhan dan fisik alam.

Green history memaparkan data historis mengenai perubahan perjalanan sejarah manusia dari waktu ke waktu dalam mengembangkan kehidupannya serta dampaknya bagi lingkungan. Perubahan-perubahan tersebut merupakan bahan pelajaran yang menarik bagi peserta didik untuk menjadi pelaku sejarah pada zamannya yaitu pelaku yang memiliki kecerdasan dalam menjaga kelestarian lingkungan pada masa kini dan masa yang akan datang. Oleh karena itu, green history bisa merupakan paradigma baru dalam pembelajaran sejarah untuk emngubah cara pandang manusia sebagai pengendali alam (anthropocentrism) ke posisi manusia sebagai bagian dari alam (ecocentrism).

Agar pembelajaran sejarah dapat dikembalikan dalam posisinya sebagai sarana belajar dari nilai-nilai humanistik masa lalu, sarana merefleksi dari tindakan-tindakan historis, dan pemberi inspirasi tentang kesadaran historis dalam berempati pada sesama manusia dan semua makhluk hidup serta fisik alam maka diperlukan dekonstruksi. Dekonstruksi, meminjam istilah Derrida (dalam Supriatna, 2016, hlm. 117) dapat digunakan untuk membongkar tatanan lama, cara berpikir dan berpandangan serta berparadigma yang tidak selaras dengan pelestarian alam. Cara pandang antroposentris yang menempatkan manusia sebagai pelaku sejarah harus dibongkar dan dikonstruksi kembali menjadi cara pandang baru yaitu ekosentrisme.

Ekosentrisme sebagai ideologi adalah relevan dengan pembelajaran sejarah berparadigma green history. Paradigma green history akan menjadi pendekatan yang relevan untuk mengembangkan kecerdasan ekologis peserta didik sebagai pelaku sejarah pada zamannya. Artinya, pelaku sejarah yang mampu menggunakan pelajaran sejarah sebagai sarana belajar dari pengalaman masa lalu untuk melakukan tindakantindakan historis pada masa kini atau tindakan berdasarkan ideologi ekosentrisme. Perubahan paradigma tersebut tidak hanya terjadi dalam tataran ideologis dari antroposentris ke 
Hena Gian Hermana

Green History dalam Buku Teks Sejarah

ekosentris, melainkan juga dalam tataran kurikulum, filsafat pendidikan, pendekatan dalam memilih dan mengembangkan materi, dan pendekatan dalam mengembangkan pedagogi.

Halaman

Kurikulum

Kelas
: 202 halaman

: (KTSP)

: SMA kelas X

Perubahan paradigma dapat dilihat dalam bagan di bawah ini.

\begin{tabular}{|c|c|c|}
\hline No & Paradigma Modernisme & Paradigma Green History \\
\hline 1 & Ideologi: antroposentrisme & Ideologi: ekosentrisme \\
\hline 2 & Kurikulum: dokumen & Kurikulum: fraksis \\
\hline 3 & Filsafat pendidikan: perenialisme dan esensialisme & $\begin{array}{l}\text { Filsafat pendidikan: konstruktivistik dan } \\
\text { dekonstruktivistik }\end{array}$ \\
\hline 4 & $\begin{array}{l}\text { Posisi peserta didik: objek. } \\
\text { Tokoh sejarah adalah pelaku sejarah }\end{array}$ & $\begin{array}{l}\text { Posisi peserta didik: subjek dan otonom pelaku } \\
\text { sejarah pada zamannya }\end{array}$ \\
\hline 5 & Fakta sejarah: tunggal dan objektif & Fakta sejarah: narasi dan subjektif \\
\hline 6 & Pembelajaran: transmisi fakta-fakta & Pembelajaran: dialog \\
\hline 7 & Pedagogi: pedagogi modern (konvensional) & Pedagogi: ekopedagogi \\
\hline 8 & $\begin{array}{l}\text { Cakupan sejarah: nasional dan sejarah politik, sejarah } \\
\text { elite }\end{array}$ & $\begin{array}{l}\text { Cakupan sejarah: lokal (termasuk kearifan lokal } \\
\text { dari tradisi lisan dalam beradaptasi dengan alam) }\end{array}$ \\
\hline
\end{tabular}

\section{METODE}

Metode penelitian yang digunakan dalam penelitian ini adalah metode analisis isi (content analysis). Menurut Mulyana (2013) metode analisis isi adalah suatu metode untuk mengumpulkan dan menganalisis muatan dari sebuah teks. Teks yang dimaksud dalam penelitian ini adalah buku teks pelajaran Sejarah yang digunakan oleh SMA kelas X berdasarkan kurikulum KTSP standar isi 2006 yang diterbitkan oleh Erlangga.

Pengumpulan data dilakukan dengan cara kajian pustaka. Penulis dalam hal ini tidak hanya mencatat sumber tertulis yang ditemukan, tetapi juga menganalisis maknanya yang tersirat. Teknik analisis yang digunakan dalam penelitian ini, penulis melakukan pemaknaan terhadap nilai-nilai peduli lingkungan yang tersirat dalam menempatkan manusia sebagai bagian dari alam atau sejajar dengan alam (green history) yang terkandung dalam buku teks pelajaran sejarah tersebut. Penulis menganggap konsep green history mengandung pendekatan nilai di dalam memberikan pemaknaan terhadap peristiwa sejarah yang dinarasikan pada buku pelajaran sejarah.

\section{PEMBAHASAN}

\section{Identitas Buku}

Dalam analisis buku teks ini, penulis mengambil 1 contoh (sample) buku teks sejarah. Pemilihan tersebut didasarkan pada kelengkapan materi dan kesesuaian materi dengan konsep green history yang akan dikaji pada bagian-bagian pada buku teks ini. Adapun secara rinci kelengkapan buku teks ini, yakni sebagai berikut.

$\begin{array}{ll}\text { Judul } & \text { : Sejarah untuk SMA Kelas X } \\ \text { Penulis } & \text { : Drs. I Wayan Badrika, M.Si. } \\ \text { Penerbit } & \text { : Erlangga } \\ \text { Tahun Terbit } & : 2006\end{array}$

Buku ini terdiri dari 7 bab, yakni Bab 1 Apa itu Ilmu Sejarah?, Bab 2 Tradisi Sejarah Indonesia di Masa Prasejarah dan Masa Sejarah, Bab 3 Prinsip-prinsip Dasar Penelitian Sejarah, Bab 4 Kehidupan Awal Masyarakat Indonesia, Bab 5 Peradaban Kuno Asia-Afrika, Bab 6 Peradaban Kuno Eropa dan Amerika, dan Bab 7 Asal-usul Persebaran Manusia di Indonesia. Dari tujuh bab tersebut, penulis hanya mengambil beberapa bab saja untuk dijadikan sebagai bahan kajian atau sumber, yaitu Kehidupan Awal Masyarakat Indonesia dan Peradaban Kuno Asia-Afrika.

\section{Kehidupan Awal Masyarakat Indonesia}

Kehidupan masyarakat berburu dan mengumpulkan makanan ini sangat sederhana. Kehidupan mereka tak ubahnya seperti kelompok hewan, karena tergantung pada apa yang disediakan oleh alam. Pada masa berburu dan mengumpulkan makanan, manusia tinggal di alam terbuka seperti hutan, di tepi sungai, di gunung, di goa dan di lembahlembah. Di samping itu, lingkungan alam kehidupan manusia pada masa berburu dan mengumpulkan makanan belum stabil dan masih liar. Binatang buas menjadi penghalang bagi manusia untuk melaksanakan kehidupannya. Dalam buku teks ini dijelaskan kehidupan sosial masyarakat pada masa berburu dan mengumpulkan makanan yang menyiratkan hubungan manusia dengan alam.

Perpindahan yang mereka lakukan itu semata-mata hanya untuk memenuhi kebutuhan hidupnya. Mereka hanya mengandalkan apa yang mereka temukan dalam hutan. Dan setelah persediaan dalam hutan habis, mereka terus mencari tempat berburu lagi untuk memenuhi kebutuhan hidupnya. Kehidupan seperti ini terjadi secara berulang-ulang dari satu tempat ke tempat lain (Badrika, 2006, hlm. 100).

HISTORIA: Jurnal Pendidik dan Peneliti Sejarah, p-issn:2620-4789 | e-issn:2615-7993 
Dari kutipan tersebut, terlihat bahwa masyarakat pada masa berburu dan mengumpulkan makanan telah menempatkan dirinya sebagai bagian dari nature dan menuntut mereka dalam memenuhi kebutuhan hidupnya selaras dengan pelestarian alam. Atau dengan kata lain, manusia pada masa itu dalam posisi yang equal dengan alam (Supriatna, 2016, hlm. 106). Selain itu, respons terhadap tantangan alam yang ditunjukkan oleh masyarakat pada saat itu merupakan bentuk perwujudan eksistensinya dalam keberlangsungan hidup. Kondisi ini memungkinkan manusia melakukan berbagai tindakan antisipatif terhadap tantangan-tantangan yang diberikan oleh alam, sehingga mereka dapat survive dalam merespons tantangan tersebut.

Toynbee (1935) melihat kondisi seperti demikian merupakan cerminan dari teori Challenge and Respons. Dalam teori tesebut diungkapkan bahwa manusia cenderung berupaya bertahan hidup dengan merespons berbagai tantangan alam yang dihadapinya. Semakin rendah tantangan yang dihadapi maka kemajuan manusia semakin rendah, sebaliknya semakin tinggi tantangan maka peradaban manusia akan hancur akibat tidak adanya kemampuan untuk mengantisipasinya. Oleh karena itu, manusia akan selalu bersifat dinamis untuk bertahan menghadapi tantangan alam yang terus berubah (dalam Supriatna, 2016, hlm. 109).

Lebih lanjut, kemampuan berpikir manusia untuk mempertahankan kehidupannya mulai berkembang. Hal ini mengakibatkan munculnya kelompok-kelompok manusia dalam jumlah yang lebih banyak serta menetap di suatu tempat. Munculnya bentuk kehidupan semacam itu berawal dari upaya manusia untuk menyiapkan persediaan bahan makanan yang cukup dalam satu masa tertentu dan tidak perlu mengembara lagi untuk mencari makanan. Dalam kehidupan menetap itu manusia mulai hidup dari hasil bercocok tanam dengan menanam jenis-jenis tanaman yang semula tumbuh liar untuk dapat memenuhi kebutuhan hidupnya. Dari pola kehidupan bercocok tanam ini, manusia sudah dapat menguasai dan mengelola alam lingkungannya beserta isinya.

Kehidupan bercocok tanam yang pertama kali dikenal oleh manusia adalah berhuma. Berhuma adalah teknik bercocok tanam dengan cara membersihkan hutan dan menanamnya, setelah tanah tidak subur mereka pindah dan mencari bagian hutan yang lain. Kemudian mereka mengulang pekerjaan membuka hutan, demikian seterusnya Pada masa bercocok tanam manusia menggunakan api untuk membuka hutan. Mereka menebang pohon-pohon berukuran besar lalu membakarnya (slash and burn) agar lahan menjadi bersih dan mudah ditanami. Sistem pertanian tersebut dikenal sebagai ladang berpindah (Badrika, 2006, hlm. 103).

Dari kutipan tersebut, terlihat bahwa kehidupan masyarakat pada masa beternak dan bercocok tanam sudah memperhatikan lingkungan dan kelestarian alam dalam menggunakan lahan sebagai cara mereka memenuhi kebutuhan hidupnya. Hal tersebut, sesuai dengan konsep green history dimana posisi manusia sebagai pelaku sejarah memiliki kewenangan untuk melakukan perubahan sepanjang perubahan tersebut memperhatikan ruang (space) dan lingkungan geografis tempat manusia berada atau perubahan yang tetap memperhatikan kelestarian alam (Supriatna, 2016, hlm. 106).

\section{Peradaban Kuno Asia-Afrika}

Peradaban lembah sungai Shindu (Indus) dan Gangga merupakan salah satu peradaban besar yang muncul di wilayah India. Sungai Shindu (Indus) dan Gangga adalah sungai yang berada di daerah India bagian utara yang merupakan daerah subur, sehingga sangat padat penduduknya. Kota MohenjoDaro diperkirakan sebagai ibu kota daerah lembah Sungai Shindu bagian selatan dan kota Harappa sebagai ibu kota lembah Sungai Shindu bagian utara. Mohenjo-Daro dan Harappa merupakan pusat peradaban bangsa India pada masa lampau.

Pembangunan kota Mohenjo-Daro dan Harappa didasarkan atas usatu perencanaan tata kota yang pasti dan teratur baik. Jalan-jalan di dalam kota sudah teratur dan lurus-lurus dengan lebarnya mencapai sekitar 10 meter dan di sebelah kanan-kiri jalan terdapat trotoar dengan lebar setengah meter. Gedung-gedung dan rumah tinggal serta pertokoan dibangun secara teratur dan berdiri kokoh. Gedung-gedung dan rumah tinggal serta pertokoan itu sudah terbuat dari batu bata lumpur.

Wilayah kota dibagi atas beberapa bagian atau blok. Masing-masing bagian atau blok berbentuk bujur sangkar atau empat persegi panjang. Tiap-tiap blok dibagi oleh loronglorong yang satu sama lainnya saling berpotongan. Dan juga dibangun gedung-gedung sebagai tempat untuk menjalankan pemerintahan. Lorong-lorong dan jalan-jalan dilengkapi dengan saluran air, sebagai tempat mengalurkan air dari rumah tangga ke sungai. Saluran-saluran itu dijaga dengan baik kebersihannya sehingga tetap berfungsi dengan baik.

Teknik-teknik atau cara-cara pembangunan rumah yang telah memperhatikan faktor-faktor kesehatan dan kebersihan lingkungan. Kamar-kamar dilengkapi dengan jendela-jendela yang lebar dan berhubungan langsung dengan udara bebas, sehingga perputaran dan pergantian udara cukup lancar. Di samping itu, saluran pembuangan limbah dari kamar mandi dan jamban yang ada di dalam rumah dihubungkan langsung dengan jaringan saluran umum yang dibangun dan mengalir di bawah jalan, di mana pada setiap lorong terdapat saluran air menuju ke sungai (Badrika, 2006, hlm. 121).

Dari kutipan tersebut, telah menunjukkan bagaimana masyarakat ketika itu sudah sangat 'apik' dalam membangun serta menata lingkungan kehidupannya dengan memperhatikan keselarasan dengan alam. Mereka telah mempraktikkan pentingnya hidup adil yang selaras dengan alam dan mempertahankan nilai-nilai kearifan lokal yang dianut masyarakat. Tindakan-tindakan tersebut akan bersifat 
historis apabila memperhatikan kelestarian alam sehingga kehidupan di muka bumi bersifat sinambung (sustainable) (Supriatna, 2016, hlm. 115).

Peradaban lembah sungai kuning (Hwang-Ho) merupakan peradaban tertua di Cina yang dimulai dari muara Sungai Kuning (Hwang-Ho, sekarang bernama Huang$\mathrm{He}$ ). Sungai Kuning atau Hwang-Ho bersumber di daerah Pegunungan Kwen-Lun di Tibet. Setelah melalui daerah Pegunungan Cina Utara, sungai panjang yang membawa lumpur kuning itu membentuk dataran rendah Cina dan bermuara di Teluk Tsii-Li di Laut Kuning. Sedangkan, di dataran tinggi sebelah selatan mengalir Sungai Yang Tse Kiang yang berhulu di Pegunungan Kwen-Lun (Tibet) dan bermuara di Laut Cina Timur.

Kemudian pada masa pemerintahan Dinasti Chin (221206 SM) terjadi kemajuan yang mencolok dalam sitem pertanian. Pada masa ini, pertanian sudah diusahakan secara intensif. Pupuk sudah dikenal untuk menyuburkan tanah. Kemudian, penggarapan lahan dilakukan secara teratur agar kesuburan tanah dapat bertahan dan terjaga. Irigasi sudah tertata dengan baik (Badrika, 2006, hlm. 126).

Dari kutipan tersebut, terlihat bahwa hubungan manusia dengan lingkungan alam telah menghasilkan tindakantindakan kreatif berupa inovasi teknologi untuk menunjang kehidupan manusia (Supriatna, 2016, hlm. 107). Hal itu terlihat dari ditemukannya 'pupuk' sebagai cara untuk menyuburkan tanah agar kesuburan tanah dapat bertahan dan terjaga.

Peradaban lembah Sungai Eufrat dan Tigris merupakan peradaban yang dikenal dengan sebutan daerah Mesopotamia. Daerah itu sekarang terletak di daerah Irak. Mesopotamia berarti daerah yang terletak di antara dua aliran sungai, yakni Sungai Eufrat dan Sungai Tigris. Daerah-daerah di sekitar daerah Mesopotamia didiami oleh bangsa-bangsa yang termasuk rumpun bangsa Semit. Pada musim hujan (dari Okrober sampai April) di Mesopotamia terjadi air bah dari kedua sungai itu. Air menggenangi daerah-daerah di sepanjang aliran sungai dan setelah surut meninggalkan lapisan lumpur yang amat subur. Di daerah-daerah itulah masyarakat hidup bercocok tanam.

Salah satu masalah utama bagi kerajaan-kerajaan yang menguasai Mesopotamia adalah bagaimana memanfaatkan banjir untuk pertanian. Caranya ialah membuat sistem pengairan yang baik. Bendungan dibangun dan telaga buatan digali untuk menyalurkan dan menyimpan air yang berlebihan di masa banjir (Badrika, 2006, hlm. 132)

Dari kutipan tersebut, terlihat bahwa hubungan manusia dengan lingkungan alam telah menghasilkan tindakantindakan kreatif berupa inovasi teknologi untuk menunjang kehidupan manusia (Supriatna, 2016, hlm. 107). Hal itu terlihat dari dibangunnya bendungan dan telaga buatan sebagai respons dari terjadinya banjir besar. Pembangunan bendungan dan telaga dimaksudkan untuk menyimpan dan menyalurkan air yang berlebihan di masa banjir

\section{SIMPULAN}

Buku teks Sejarah untuk SMA merupakan salah satu bentuk material yang digunakan untuk kepentingan pembelajaran di sekolah. Di dalam penulisannya, buku teks Sejarah harus menyertakan nilai-nilai yang penting pada setiap peristiwa-peristiwa sejarah yang di narasikan, terutama nilai-nilai yang memiliki relevansi dengan lingkungan sekitar fisik alam yang menunjang keberlangsungan (sustainability) kehidupan manusia. Hal ini terjadi karena cara pandang teori kritis dan pedagogi kritis yang menghendaki adanya proses pembelajaran yang memberdayakan kesadasaran tentang independensi individu terhadap hegemoni suatu kelompok kekuasaan atas kelompok lain. Atau dengan kata lain, pembelajaran sejarah dapat dijadikan cara untuk mendidik siswa dan komunitas belajar untuk memahami, menyadari, dan mempraktikkan pentingnya hidup adil yang selaras dengan alam dan mempertahankan nilai-nilai kearifan lokal yang dianut oleh masyarakat.

\section{REFERENSI}

Buku

Badrika, I Wayan. (2006). Sejarah untuk SMA jilid 1 Kelas X. Jakarta: Erlangga.

Hamalik, O. (2008). Proses Belajar Mengajar. Jakarta: PT Bumi Aksara.

Hasan, S.H. (2012). Pendidikan Sejarah Indonesia Isu dalam Ide dan Pembelajaran. Bandung: Rizqi Press.

Mulyana, A. \& Darmiasti. (2009). Historiografi di Indonesia: Dari Magis-Religius Hingga Strukturis. Bandung: PT Refika Aditama.

Mulyana, A. \& Gunawan, R. (2007). Sejarah Lokal: Penulisan dan Pembelajaran di Sekolah. Bandung: Salamina Press.

Peraturan Menteri Pendidikan Nasional (Permendiknas) No 11 Tahun 2005

Purwanto, B. \& Adam, A.W. (2005). Menggugat Historiografi Indonesia. Yogyakarta: Ombak.

Sadiman, et.al.(2007). Media Pendidikan. Jakarta: PT Raja Grafindo.

Supriatna, N. (2016). Ecopedagogy: Membangun Kecerdasan Ekologis dalam Pembelajaran IPS. Bandung: PT Remaja Rosdakarya.

\section{Jurnal dan Makalah Prosiding}

Ahmad, Tsabit A. (2013). Pembelajaran Sejarah Berwawasan Lingkungan. Indonesian Journal of Conservation (IJC), 2(1), hlm. 74-83.

Aisyah, S. (2015). Kurikulum dan Kontroversi Buku Teks Sejarah dalam KTSP. Jurnal Pendidikan IPS, 1 (9), 17941804.

Artun, Hüseyin \& Tuncay Özsevgeç. (2016). A Study on The Evaluation of The Applicability of An Environmental Education Modular Curriculum. International Journal of Environmental \& Science Education, 11(15), hlm. 7318- 
7347.

Foster, D.R. (2010). “Conservation Lessons \& Challenges from Ecological History”. New Hamspire U.S.A: Journal of Ecology, Vol. 76.

Gadotti, M. (2010). Reorienting Education Practices towards Sustainability. Journal of Education for Sustainable Development, DOI: 10.1177/097340821000400207, 4(2), hlm. 203-211.

Kahn, R. (2008). From Education for Sustainable Development to Ecopedagogy: Sustaining Capitalism or Sustaining Life? Green Theory \& Praxis The Journal of Ecopedagogy, DOI: 10.3903/gtp.2008.1.2, 4(1), hlm. 1-14.

Mulyana, A. (2013). Nasionalisme dan Militerirsme: Ideologisasi Historiografi Buku Teks Pelajaran Sejarah SMA. Paramita, 23 (1), hlm. 78-87 ISSN: 0854-0039. DOI: http://dx.doi. org/10.15294/paramita.v23i1.2498.

Prabawani, B., dkk. (2017). Primary Schools Eco-Friendly Education in the Frame of Education for Sustainable Development. International Journal of Environmental \& Science Education, 12(4), hlm. 607-616.

Purwanta, H. (2012). Evaluasi Buku Teks Pelajaran Sejarah Pada Masa Orde Baru. Cakrawala Pendidikan, 31(3), 424-440.

Supriatna, N. (2011). Konstruksi Pembelajaran Sejarah yang Berorientasi pada Masalah Kontemporer Pembangunan. Mimbar, 27(1), hlm. 21-30.

Supriatna, N. (2014). Green History Dalam Kurikulum 2013: Belajar Dari Pengalaman Historis Hubungan Manusia Dengan Alam. Dalam Agung, D.A.G (ed.) Prosiding Seminar Nasional 2014 Pembelajaran Sejarah di Tengah Perubahan, pp. 64-77, Malang: Fakultas Ilmu Sosial Universitas Negeri Malang.

Utami \& Widiadi. (2016). Wacana Bhineka Tunggal Ika dalam Buku Teks Sejarah. Paramita, 26(1), hlm. 106-117.

Warju, dkk. (2017). Evaluating the Implementation of Green School (Adiwiyata) Program: Evidence from Indonesia. International Journal of Environmental \& Science Education, 12(6), hlm. 1483-1501. 
Hena Gian Hermana

Green History dalam Buku Teks Sejarah

HISTORIA: Jurnal Pendidik dan Peneliti Sejarah, p-issn:2620-4789 | e-issn:2615-7993 